\title{
Clash of Images: 9/11 \& Terrorism
}

\author{
Esmaeil Zeiny ${ }^{1} \&$ Noraini Md. Yusof ${ }^{1}$ \\ ${ }^{1}$ Institute of Malaysian and International Studies (IKMAS), National University of Malaysia (UKM), Malaysia \\ Correspondence: Esmaeil Zeiny, Institute of Malaysian and International Studies (IKMAS), National University \\ of Malaysia (UKM), 43600, Bangi, Selangor, Malaysia. Tel: 60-17-879-9036. E-mail: mehdizeiny@gmail.com
}

Received: March 4, 2015 Accepted: May 6, 2015 Online Published: June 13, 2015

doi:10.5539/ass.v11n16p246

URL: http://dx.doi.org/10.5539/ass.v11n16p246

\begin{abstract}
The world we live is fraught with visual images. These images are central to how we communicate and represent in our lives. They are of significance in the imagination and construction of cultural identities. Visual communication is more ubiquitous than ever before because images have the ability to quickly influence viewers both cognitively and emotionally. Many of the images that we see daily are ideological images such as the anti-Muslim or anti-American pictures triggered by 9/11. This paper examines the $9 / 11$ images and the consequent images of 'war on terror.' Utilizing and extending Gillian Whitlock's theory of 'soft weapons' to images, we argue that images which have long been recruited as propaganda can act as weapon in soliciting support and sympathy by generating hatred. We shed light on the fact that the clash of images is indicative of current image culture where images are powerful tools of persuasion when they array against and engage with one another.
\end{abstract}

Keywords: clash, images, 9/11, Muslim, west

\section{Introduction}

It is a well-understood fact that images have a strong power in shaping people's perception. Media which exclusively used to rely on words now "have less text and more images than in the past" (Lutz \& Collins, 1993, p. 4). Visual communication is more ubiquitous than ever before because images have the ability to quickly influence viewers both cognitively and emotionally. The world we reside has been loaded with visual images. These images are pivotal to how we communicate and represent in our surroundings. Visual images are of paramount importance in the imagination and construction of cultural identities. As Mirzoeff (1998) and Lutz and Collins (1993) argue, visual images are crucially significant because in this era of time the public allocate more time to the acquisition of knowledge through visual media. Encircled by the widely circulated images, the perceptions and dreams of the grassroots are easily shaped. Since the shift to visual communication, images have always been influencing traditional values of the societies around the globe and its impact on culture can be detected in everyday facet of life. The fascination with the visual communication produces an anxiety about the influences of images. The potential power of images stems from the dynamic of social powers and ideologies. Images are important tools through which "ideologies are produced and onto which ideologies are projected" (Sturken \& Cartwright, 2001, p. 21).

In this age of globalization, images, which have never been mere illustrations, are the extension of ideologies. A telling example of ideological images is anti-Muslim/American pictures triggered by $9 / 11$. It all began with 9/11 itself when images of the Twin Towers burning and rescue workers appearing from Ground Zero bombarded the media. Following the 9/11 attacks, the anti-Muslim images have regained alarming currency in the Western visual discourses. Prior to 9/11, the mass media of the West, especially America bombarded the people with anti-Iranian/Muslim images after the 1979 Iranian Revolution and the Hostage Crisis in which fifty-two American diplomats and citizens were held hostage for 444 days in Iran. In both cases, the Western mass media collapsed the Muslim communities into terrorism. To show that Muslims were terrorists, the Western media became fraught with images of $9 / 11$ event, bearded Muslim men carrying guns and voiceless veiled women. These anti-Muslim images have been heavily influencing the Western media since 9/11. The bewildering cluster of 9/11 images, anti- Muslim signs and symbolic resources left an indelible mark in the psyche of Westerners. In retaliation to the anti-Muslim images in the West, anti-Western images began to appear in many Muslim countries. Images of hooded prisoners of Abu Gharib and shooting of innocent civilians in Afghanistan and Iraq flooded the media in the Muslim countries. These images were publicized to symbolize the brutality of West. 
These anti-West/Muslim images have been competing furiously to win hearts and minds of the people. They clash with one another in inciting abhorrence, anger and winning people over to their side. In a world that has taken a "pictorial turn" (Mitchell, 1994), it is not surprising to see that terrorism and military intervention have taken identical turns. From the crash of the World Trade Center to stories of Abu-Gharib prisoner abuse and terrorist decapitation, outlandish and appalling images filled our everyday life.

\section{Images of $9 / 11$}
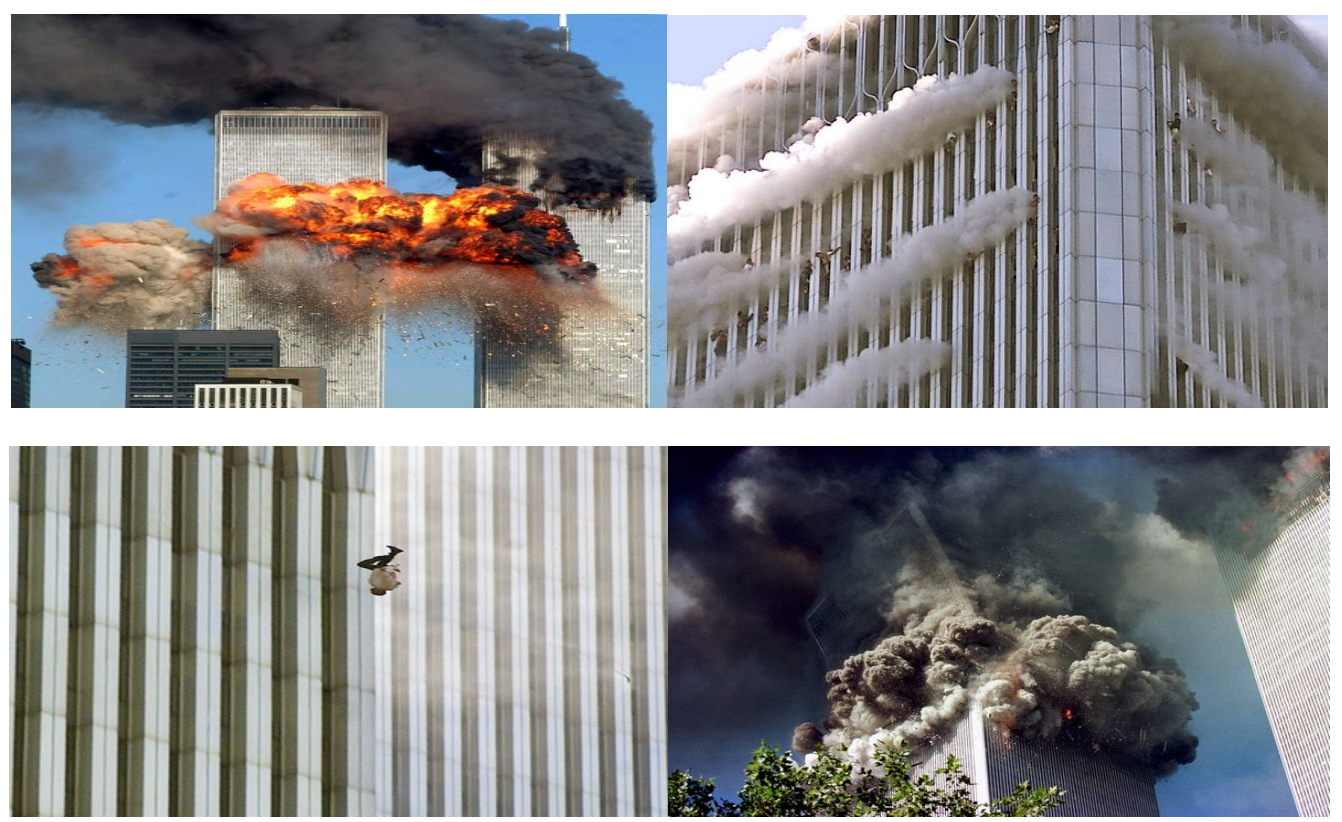

Figure 1. Images of 9/11, courtesy Getty Images

9/11/2001 is a day Westerners, especially American will never forget. It was a day when four planes were hijacked, two of which were flown into the World Trade Center towers, one was directed into the Pentagon building and the other was crashed in a field. The attacks were launched by the Muslim terrorist group Al-Qaeda which killed almost 3,000 people. Minutes after the crash into the World Trade Center and Pentagon, media outlets reported the atrocities. The 9/11 attacks became one of the most breathtaking media drama in history. Images of crashing the World Trade Center as the heart of America's symbolic power and Pentagon as the symbol of U.S military power abounded the media. Images of Twin Towers billowing with smoke and fire prior to their collapse, people fleeing the fire by hanging from the windows and jumping driven by the scorching temperatures and by the brink of fires, and the collapsing of the towers will forever remain ingrained in the memory of the public (Figure 1). They have been etched in the mind of many Americans. These images which became symbolic representation of terrorist attacks rose to iconic status as they possessed the strength to impact people and produce a public memory of the incident (Hatfield, 2006).

In the days, weeks, months and years after $9 / 11$, the media was inundated with endless images of the planes crashing, the twin towers falling, people looking for their missing ones and the nineteen Arab Muslim men responsible for the terrorist attacks. 9/11 Photographic exhibition was launched in 2002 to keep the memory alive and since then, each year on September 11 memorials take place to commemorate the tragedy. To inaugurate the first exhibition of After September 11: Images from Ground Zero in 2002, the then US Secretary of State, Colin Powel (2002) states: "we send these chilling photographs out to the world as a remembrance and as a reminder: a remembrance of those who perished, and a reminder of our commitment to pursuing terrorists wherever they may try to hide." Supported by the State Department, this exhibition was held in more than 60 countries by the end of 2004. Kennedy (2003) argues that this exhibition was organized to keep and shape a public memory of the 9/11 event and its aftermath. US State's backing of the exhibition is suggestive of the significance of visual culture in fighting the terrorism. The depth of the destruction was captured and circulated to symbolize the terror. The degree of the destruction is felt every time a 9/11 image, especially the image of Twin Towers collapsing, is seen. The psychological effect of these images was dramatic. The images were replayed so relentlessly that concerns were raised about the impact of viewing these images (Hankiss, 2001). 
Americans felt insecure as they had seen the once symbol of American finance and culture, World Trade Center crashed into pieces; many Americans identified themselves with the Twin Towers. George Lakoff (2004, p. 53) states:

The devastation that hit those towers that morning hit me. Buildings are metaphorically people. We see feature-eyes, nose, and mouth- in their windows. I now realize that images of plane going into South Tower was for me an image of a bullet going through someone's head, the flames pouring from the other side like blood spurting out. It was an assassination. The tower falling was body falling. The bodies falling were me, relatives, friends. Strangers who had smiled as they had passed me on the street screamed as they fell past me. The image afterwards was hell: ashes, smoke and steam rising, the building skeleton, darkness, suffering, death.

Lakoff's account of the destruction of the Twin Towers offers a lucid viewpoint of the terror and the devastation that happened that day. Since 9/11 continues to become a distant incident, "these images will serve as a reminder of the vulnerability and the terror many felt that morning" (Hatfield, 2006, p. 91). Images of a woman enveloped in ash, the smoldering remains of the World Trade Center, and firefighters and rescuers amidst the debris in Ground Zero brought tears to many people and devastated them emotionally (Figure 2). These pictures became lasting images as they symbolize an unfathomable catastrophe. Not only do they create and bolster senses of susceptibility and terror, but they also reinforce feelings of destruction and trauma. As already noted, these images rose to be iconic images as they become particularly arresting when they bespeak significant events in public life. Iconic images are pictures that are begotten either in print or electronic media and usually possess four characteristics: these images are1) "recognized by everyone within a public culture" 2) "understood to be representations of historically significant events" 3) "objects of strong emotional identification or response" and 4) "regularly reproduced or copied across a range of media, genres, and topics" (Lucaites \& Hariman, 2001, p. 37). 9/11 images are all iconic as they are known by everyone within a public culture and represent an important historical event. They are also objects of emotional identification and are systematically reproduced in all forms of media as remembrance and reminders of the devastation.
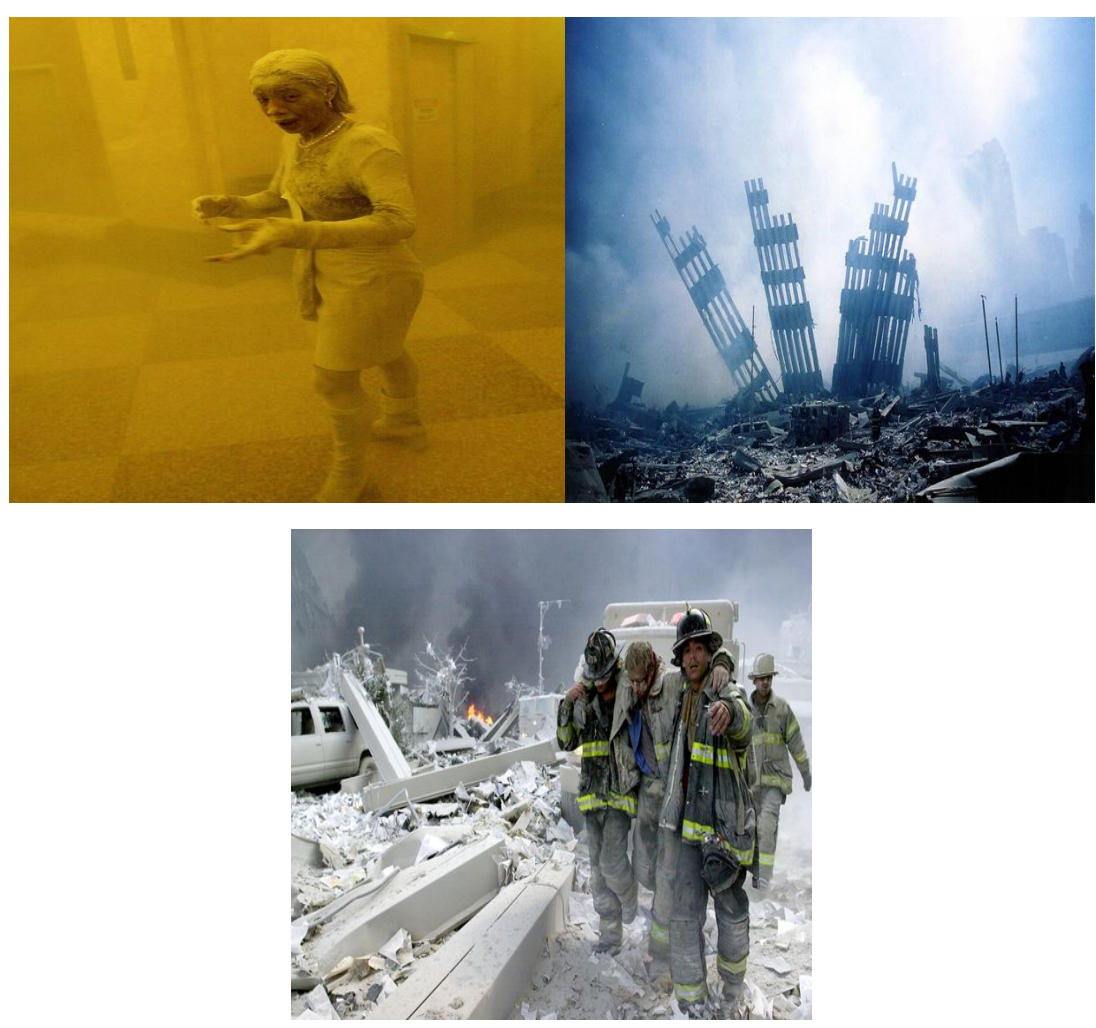

Figure 2. Images of 9/11, courtesy Getty Images

The American public was shaken dramatically by realizing that its space and citizens were susceptible to the kind of disastrous terror attack took place that morning (Kellner, 2007). Suddenly many Americans, who were sure of their safety, invulnerability and supremacy, lost their sense of certitude. Bailey Jones $(2007$, p. 9) argues that this 
"loss of confidence brought about an ugly wave of xenophobia, a crisis of identity that led to a sealing off from everything perceived as different and foreign." Xenophobia and racism became common sentiments of many Americans. What helped the xenophobia and racism flourish was President Bush's speech of 'Axis of Evil' after the event of 9/11 addressed to Iran, North Korea and Iraq, which was an obvious demarcation of West/East. American fear of global terrorism has augmented antagonism towards anything foreign, especially Muslims because the 9/11 attacks were carried out by Al-Qaeda. Since then, the Western fear-mongering media has posed a fear of anything Muslim in grass roots' opinion. It created a noticeable increase in violence and abhorrence towards Muslims in the West. Thoughts like "Muslims are going to terrorize us and threaten our very way of life" became prevalent and ran through many conversations those days. The 9/11 images had played an important role in escalating cycle of fear and violence against Muslims.

\section{Clash of Images}

Accompanying 9/11 images were anti-Islam images in which Islam and 9/11 were linked; anti-Islamic images and mottos were gaining currency not only in media but they could also be seen as murals and on T-shirts (Figure 3). This sort of images increased the hostility towards Muslims so much so that post $9 / 11$ West has witnessed many hate crimes against Muslims and Arabs. According to a report by FBI, the hate crime against Muslims has increased by 1,600 percent from 2000 to 2001. Hundreds of aggressive events experienced by Muslim and Arabs were documented, several murders have happened, many airline passengers who were Muslims or look like one were refused entry to the planes, many Arabs and Muslims were openly discriminated at work, they have received hate mails and their properties, mosques and their community centers were set on fire or vandalized (Alsultany, 2013). The root cause of this aggression was the prevalence of $9 / 11$ and anti-Muslim images acted as catalyzers to gain people support for 'war on terrorism.' America and its allies were ready to launch the 'war on terror' and the best way to commence it was to manufacture consent.

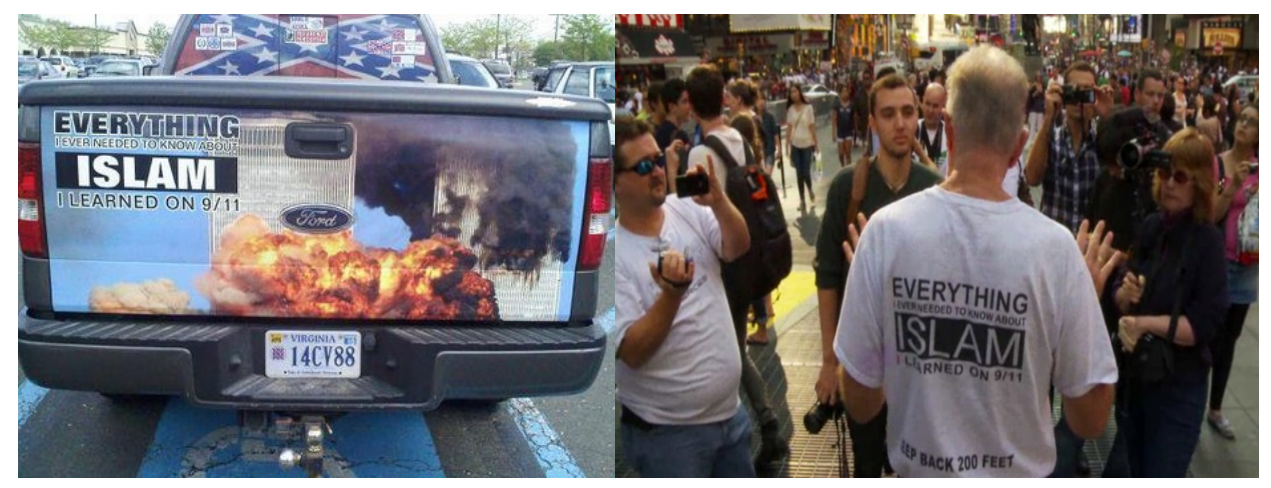

Figure 3. Anti-Islam images

To have a sound justification to attack terrorism, the West, mainly America, resorted to the issue of women's right in the country of terrorism, the Middle East. Soon the country was saturated in images of turbaned bearded Muslim men carrying guns and beating up veiled voiceless Muslim women (Figure 4). All of a sudden, sympathetic depictions of Arab and Muslim women proliferated the West. The plights of Muslim women became a central topic for Western politicians. In a radio address to the nation on November 17, 2001, Laura Bush asserted: "Life under the Taliban is so hard and repressive, even small displays of joy are outlawed. Children aren't allowed to fly kites; their mothers face beatings for laughing out loud." To conclude her remarks that day, she stated "the brutal oppression of women is a central goal of the terrorist." Zeiny Jelodar et al. (2014) argue that "concomitant with claims about punitive action for this [terrorist] attack [of 9/11], the West administration accused Taliban [and Al-Qaeda] with violations of women's right" (60). Their apparent feminist motivation to wage a war in the Middle East where the rights of women were infringed and abrogated, where women were treated as tyrannized helpless victims worked well in producing consent. The West put a great deal of effort in persuading people that the war waged had a civilizing mission in the name of women's rights among other justifications of democracy such as eradicating weapons of mass destruction and fighting terrorism. The Taliban that the USA and its allies once supported during the influence of Soviet in Afghanistan became the target of military attack after September 11 for violating women's rights (Jabbra, 2006). 


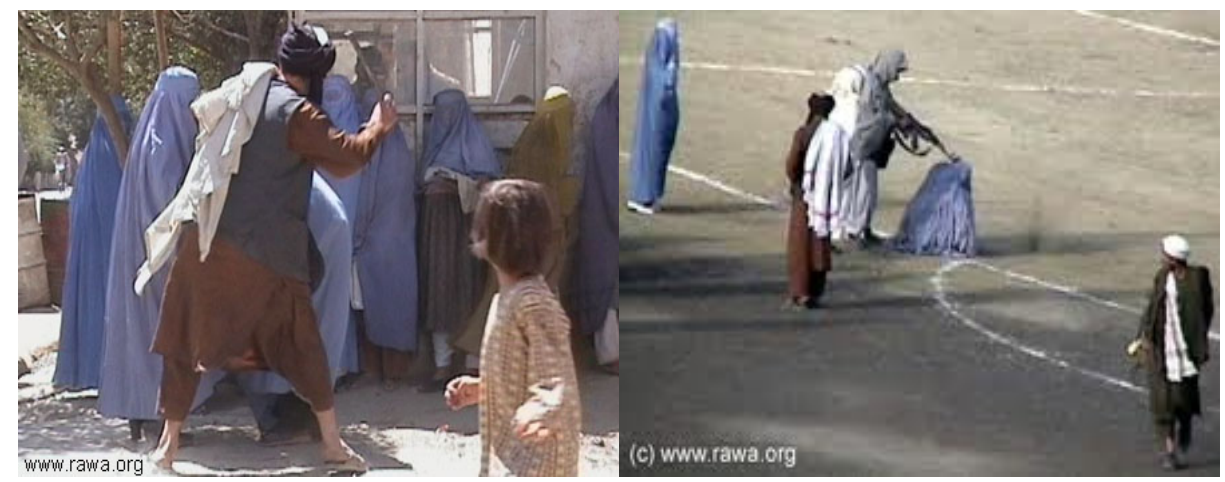

Figure 4. images of women living under Taliban, courtesy RAWA

Images of Muslim women as veiled, powerless, silent, abused and victims of patriarchal societies bombarded the Western countries. Images about the oppression of Muslim women have been in demand. Images with titles such as "Under the Veil," "Lifting the Veil," "Beneath the Veil," "Under the Burka" and "Unveiling Freedom" promised the Western viewers to take them "beneath the veil" to bring to light the mysterious lives and reveal for the Westerners why Muslim are terrorists. These images show Islam as a backward and terrifying religion; Islam is shown a religion in which women are facing female genital mutilation, being beaten and killed for love and violating the dress code, being stoned to death for adultery and unable of getting a child custody in cases of divorce (Alsultany, 2013). To corroborate that these images are true representation of Islam and Muslim women, several Muslim women have been asked to go on air to explain women's plights in Muslim countries. One of these women is Ayan Hirsi Ali from Somalia who has written books about the incompatibility of Islam with democracy and has talked widely about the situation of women in Muslim countries. Hirsi Ali has made a lucrative career by defecting from Islam and becoming spokespersons for its innate brutality. Invited to CNN's Anderson Cooper 360 to talk about Muslim women and commenting on a Saudi Arabian woman who was raped and lashed, Hirisi Ali (2007) said:

For all women, the reality is stay in the house unless you have a pressing need to go outside. If you have a pressing need to go out you must wear the veil. If you marry, your husband can say three times, "I divorce you," and you are divorced. The other way around is not possible. The problem of child brides in Saudi Arabia is as common as drinking espresso coffee in Italy. It is because the Prophet Muhammad married a nine-year-old girl, every man in Saudi Arabia feels that he can marry a minor or he can marry off his daughter who is underage. You will be stoned, flogged if you commit or give the impression that you may have committed adultery. It is not nice being a woman in Saudi Arabia.

She has reduced Islam and its culture to women oppression. Muslim women like Hirsi Ali have been recruited to denounce Islam in its entirety. Their insider status legitimizes their narratives and the images of oppressed Muslim women. Having listened to their talks or read their narratives, the public's belief in images would be consolidated. They are contributing in paving the way and rationalizing attacks on Muslim countries. Dabashi (2011) argues that Hirisi Ali and her ilk are native informers who are sophisticated and enough well-educated to disguise their flattery towards their employers and audiences. They fake authority when telling their white masters what they desire to hear, not what they need to know, and they are rewarded by being labeled "voices of dissent" by their white masters (Dabashi, 2011, p. 17). He argues that the native informers play a key role in making the inversion of truth by fantasy appear rational. The native informers' narratives became pervasive all over the Western market and this market was looking for the best and the smartest individuals with "a pigment to their complexion who could tell their tales with an accent to their English" (2011, p. 16). This was the time for the native informers to step forward to "oblige, accommodate and entertain" as American military was preparing to attack the Muslim world (2011, p. 16).

Many of these native informers, such as Seyyed Vali Reza Nasr and Ray Takeyh, were hired by the US military; some of them, such as Azar Nafisi and Foad Ajami, were adopted by key Figures in the military establishment, and some, such as Ayaan Hirsi Ali, by neo-conservative think-tanks (Dabashi, 2011, p. 17) to persuade the public that women in Muslim countries are in dire need of liberation. These Muslim commentators are the modern day neo-orientalist whose stories depict Islam as a tyrannical religion where human liberty is defeated. Their narratives of firsthand experience bolster the anti-Muslim images that Islam poses a threat to women. What confers them space and legitimacy was the fact that they have written their stories under the alibis of defending 
human rights, women's rights and the civil rights of Muslims in Islamic countries. Dabashi (2011, p. 17) argues that America turns to these native informers or the "expatriate intellectuals" to tell the targeted grass roots that they plan to "invade, bomb, and occupy their homelands for the population's own good." However, the primary target of this propaganda is the American themselves to make sure that they are ordained to save the world from its evils and that they are superior and noble people (2011, p. 18).

The persistent proclivity to represent women as victims is to convince the Westerners that women from Middle East need to be rescued from the brutalities of Muslim men. This exotic exhibition of many images of Muslim women is absolutely haunting. These images solicit sympathy for a Western viewer as it is very hard for them to see these images and resist interpellation. The Westerners desire to liberate and recognize Muslim women by lifting the burka and bringing them "barefaced in the West?" (Whitlock, 2007, p. 47). Pulling the Western eyes behind the chador or under the burka is an effective rhetorical approach; it draws out both "sympathy and advocacy" that can be put to quite "various political and strategic uses" (Whitlock, 2007, p. 47). These sorts of images can be called 'soft weapons' as the producers employ strategies to elicit sympathy from the Western readers. They can pack a punch in the world. When the Western viewers see these images from the Middle East, they feel sympathy for the people living in those societies. The impact of these images is to the extent that Western viewers feel "these women are just like us" but living in a miserable and agonizing condition. This sentiment, the feeling of human engagement, creates a room for dialogue. This is what makes the current forms of images "potent yet flawed weapons for cross-cultural engagement and the pursuit of human rights" (Whitlock, 2007, p. 3).
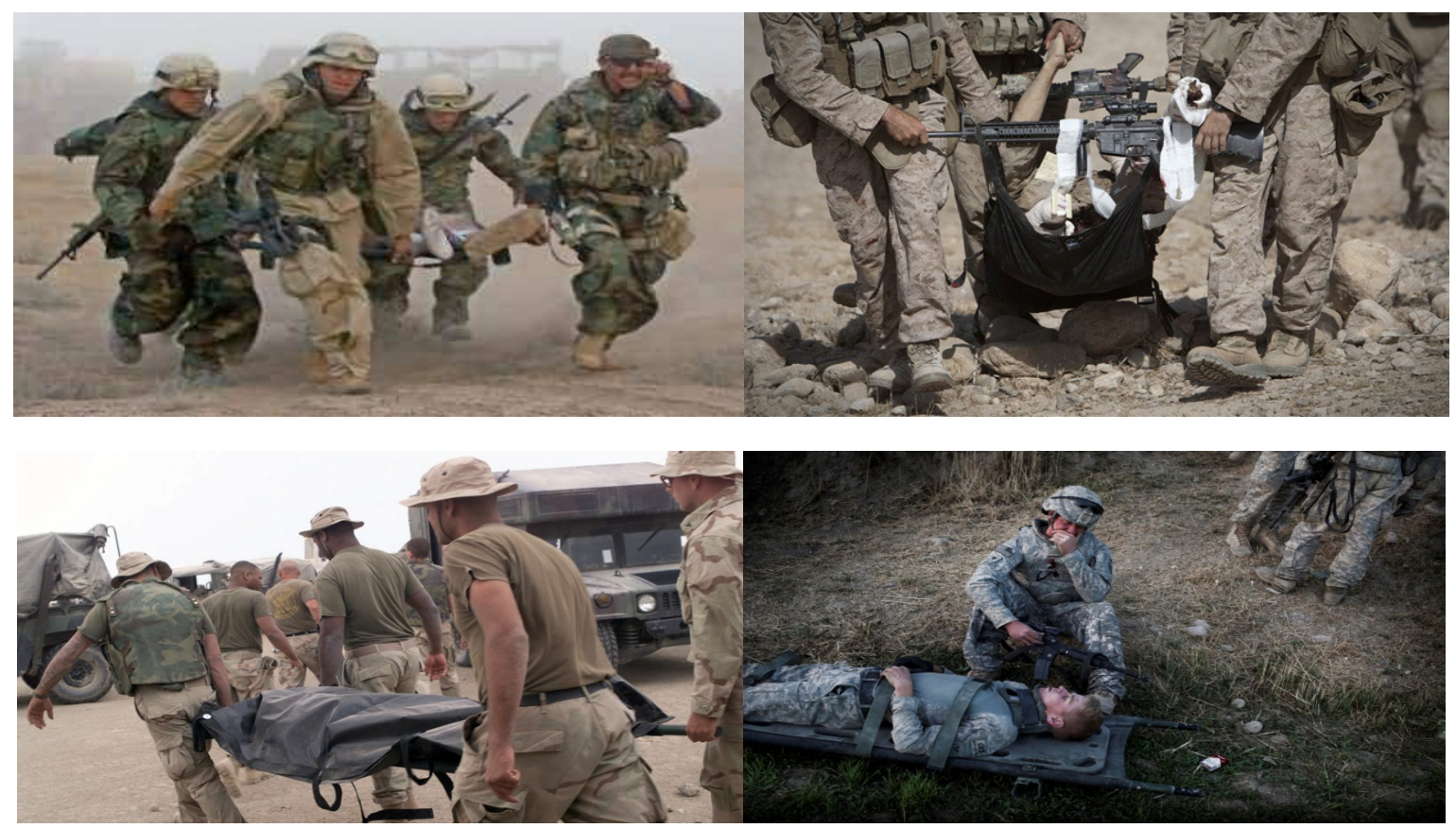

Figure 5. Wounded/dead soldiers at the battlefield, Google images

When the 'war on terror' began in October 2001 as a response to 9/11 attack in Afghanistan and as it was dragged on and extended to Iraq, the visual culture of conflict began to emerge. Although visualizing the event was a difficult task as it was fought against an elusive enemy, America and its allies made it feasible by sending journalists to the war zones. It was a brilliant strategy to let the journalists live the life of the soldiers and let them see what the soldiers see. Journalists' coverage of the 'war on terror' elicited sympathy as they aired images of wounded/dead American/Western soldiers (Figure 5). The overwhelming majority of images of wounded soldiers became a means of soliciting support for the military attack in Afghanistan. As a response to these images, initially Al-Qaeda and then the attacked Muslim produced images that increased the hostility towards America and its allies. Both parts understood well the importance of images. Images of American and its allies killing civilians went viral (Figure 6) and increased the anti-West sentiment. These images vilified American and its allies in Muslims' estimation. It is undeniable that both sides realized that media images are half of the war effort. To them, the media image was as significant as the action itself. 


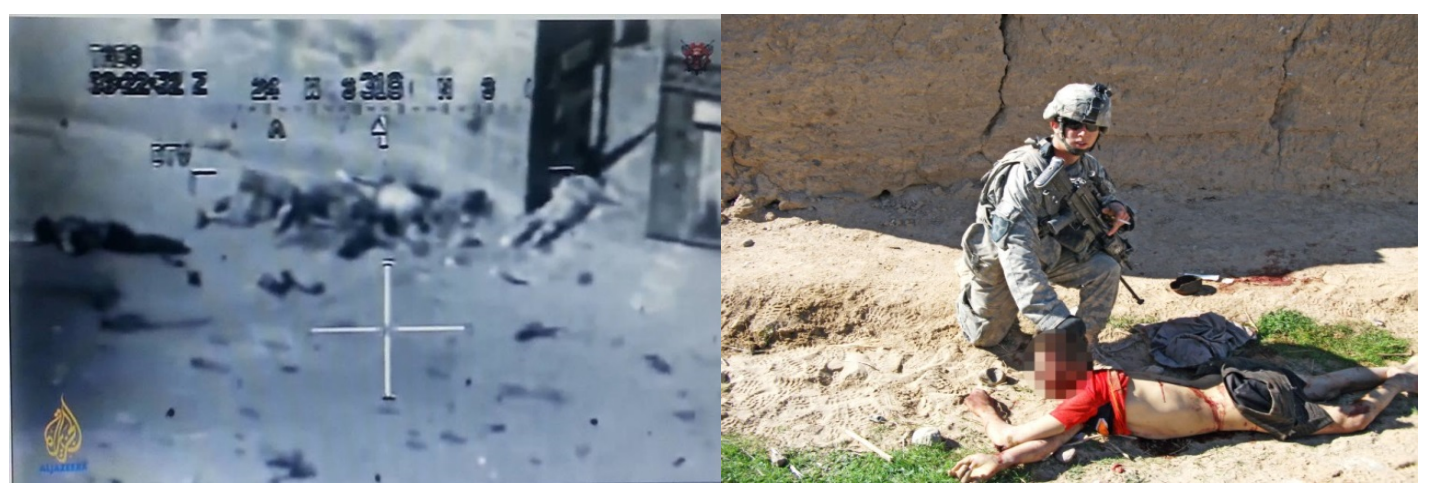

Figure 6. Killing Afghan and Iraqi civilians. Courtesy Al-Jazeera news \& Google image

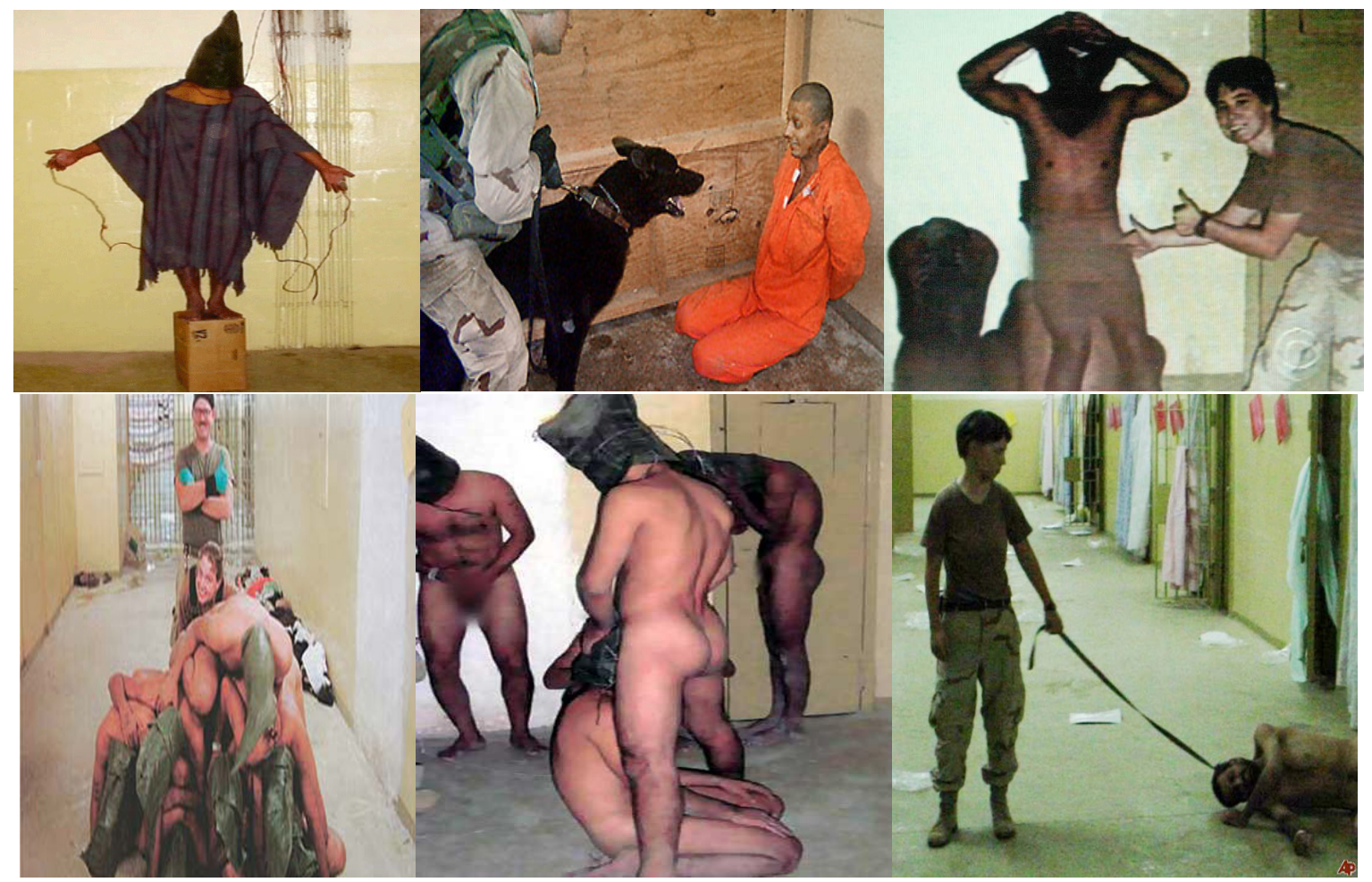

Figure 7. Images of Abu-Gharib prisoner abuse

Al-Qaeda has started 'Electronic Jihad' by producing images that called for jihad against America and its allies. Images of Osama Bin Laden inviting Muslims to join them in a jihad against America were distributed widely. What dramatically increased anti-American sentiments amongst Muslims and even Westerners were the images of Abu-Gharib prisoners. When the Abu-Gharib images became public in April 2004, they were instantly turned into the defining symbols of Western arrogance, exploitation and brutality in their crusade against Muslims. Visual media which were meant to elicit sympathy and gain support for the military intervention in Afghanistan and Iraq, had now turned around to damage its masters. Mirzoeff (2006) argues that as soon as the photographs of Iraqi prisoners of Abu- Gharib became public property, "it seemed as if the deployment of visual media as a weapon by the United States had suffered its inevitable blowback" (21). Photographs of leashed hooded prisoners, detainees attacked by guard dog, an American woman soldier pointing to prisoners' genitals, pyramid of naked prisoners, prisoners' compelled masturbation and fellatio (Figure 7) hurt the images of Americans and the British as these images backfired disastrously. The U.S. and British authorities employed interrogation techniques to exploit religious sensitivities of Muslims designed to "affront Muslim religious taboos and use sexual shame as a method for breaking down prisoners' resistance to interrogation" (Sun \& Matthews, 2004). Abu-Gharib images became the greatest public relation disaster for America and its allies. 


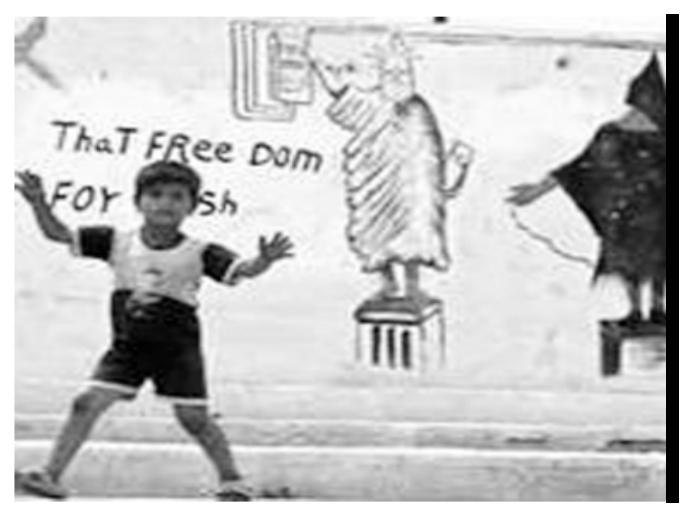

Figure 8. Hooded man prisoner mural in Baghdad

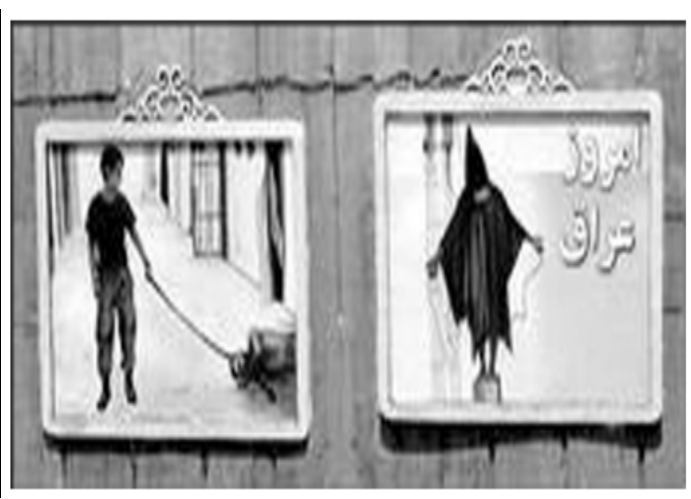

Figure 9. Abu-Gharib murals in Tehran
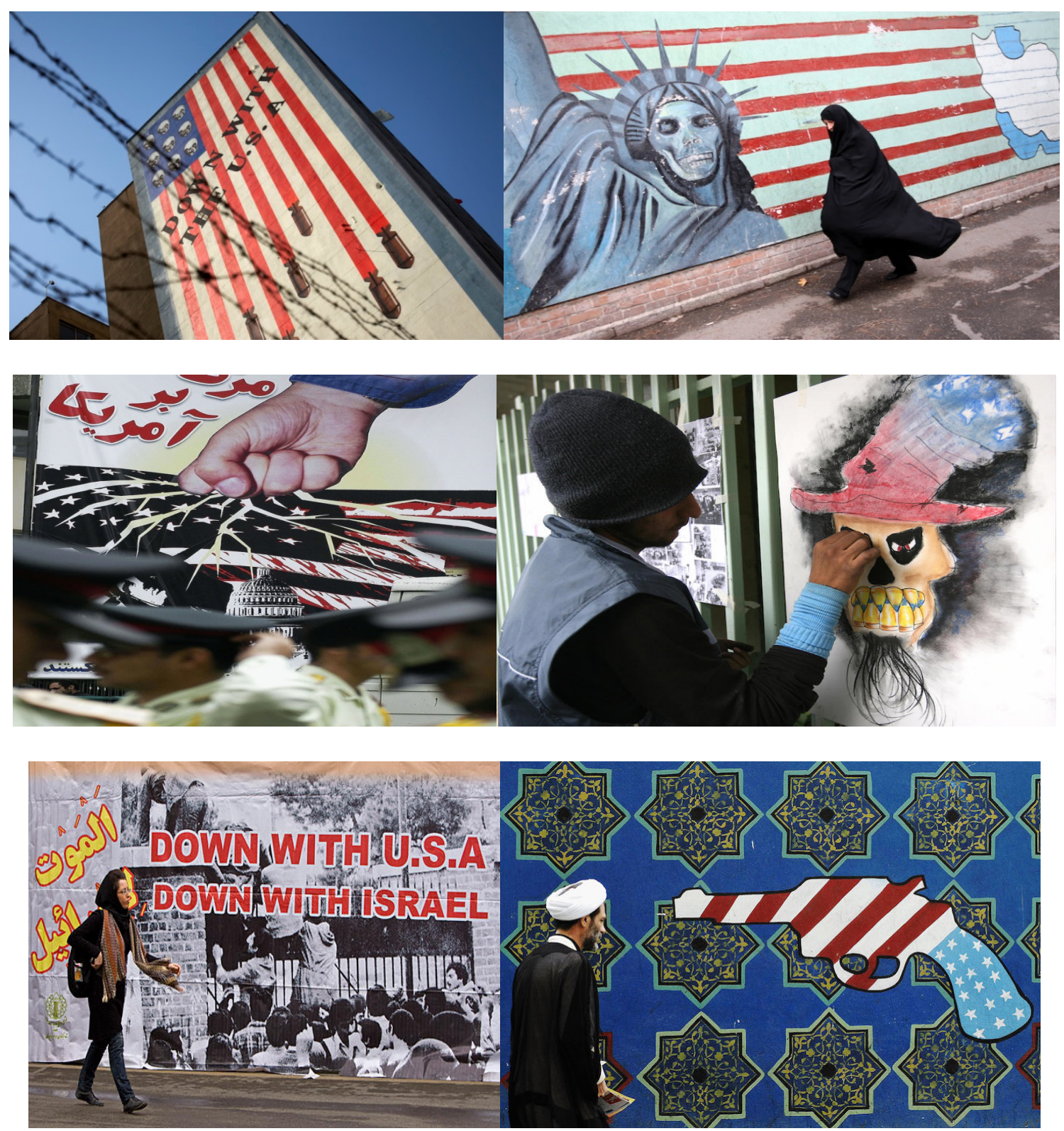

Figure 10. Anti-American murals in Tehran 
These sordid images sparked disgust and abhorrence; they portray American and its allies as hypocrite and dangerous. These images contradicted the U.S dominant discourse of human rights and had considerable impact on public imagination and their historical consciousness. These images also rose to iconic status as they were instantly appropriated and re-circulated in a wider culture. They had global cultural ramifications and continue to be re-distributed in murals, posters, ads, comics and websites (Anden-Papadopoulos, 2007). These images of Abu-Gharib were metamorphosed into anti-war and anti-American images where the pictures functioned as sites of defiance and resistance to the very acts they represent (Apel, 2005). The most symbolic image of Abu-Gharib abuse scandal is the picture of the hooded prisoner standing on a box which appeared countlessly in protest art images. His wide open arms stand for Christ on the cross which conjures up devotional images that depict revered and tormented Figures that remain decent in spite of their humiliation (Mitchell, 2004). The hooded man was regenerated as a mural in Baghdad (Figure 8). His opened hands are connected to an electric grid, and to his right, a white-hooded statue of liberty is painted with his hand on the switch. The words on the wall read "The Freedom for Bush" which signifies the death of Muslims. This hooded man has made it to the murals in other Muslim countries such as Iran along with images of Lynndie England keeping a detainee on a leash (Apel, 2005) (Figure 9). The rationale for juxtaposing these two images is the transformation of these private shots into public visibility (Anden-Papadopoulos, 2007) and to increase the anti-American sentiments. It is worthy to note that Anti-American murals are by no means a new phenomenon in Iran. Iranians have been surrounded by these state-sponsored anti-American murals (Figure 10) since the 1979 Revolution when Ayatollah Khomeini seized the power. Needless to say the main objective of filling a society with anti-American images is nothing but to incite hatred towards Americans.

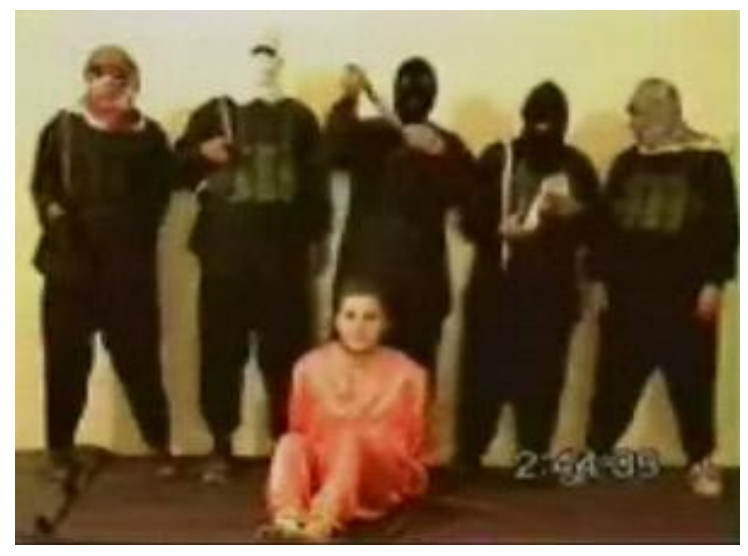

Figure 11. Beheading of Nicolas Berg

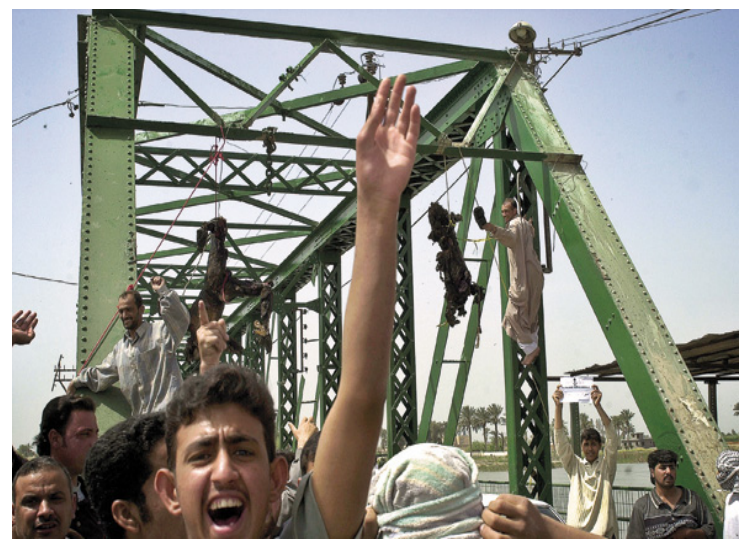

Figure 12. Two charred American bodies hanging from a bridge in Fallujah, courtesy Khalid Mohammed

Al-Qaeda was clever in exploiting the Abu-Gharib pictures to recruit more mujahidin to launch its operations. Abu-Gharib images drove jihadists to new lengths. Al-Qaeda decided to retaliate by beheading an American contractor (Figure 11). The American contractor, Nicholas Berg was kidnapped and executed in May 2004. The event was filmed as they wanted the images in the film to act as weapon. He was clothed in orange uniform and was posed lower in front of the group. His captors were wearing dark clothes and were standing behind him 
which suggests the towering and dominating Figure. The decapitation of the American hurt the image of Islam, particularly Al-Qaeda. Other images such as the two charred American bodies hanging from a bridge in Fallujah amidst a happy crowd escalated anti-Islamic sentiments (Figure 12). The contrast of celebration amidst horror is conspicuous in this image. The images terrorized the viewers and alienated one-time sympathizers but at the same time they expressed the disapproval of American intervention. The public in America was told by native informers such as Foad Ajami that the American soldiers would be greeted with flowers and sweets by the Iraqis which in turn encouraged their neoconservative white masters in telling the Western public that Iraq's invasion would be a cakewalk. Although it was said that American troops would be back from Iraq by the end of 2013, this assumed cakewalk is still in progress today after a period of decade with no end in sight.

This clash of images goes on as long as the U.S. led intervention under the project of 'war on terror' in Afghanistan, Iraq and Pakistan persists in spite of eliminating Osama Bin Laden. The 'war on terror' has turned into an incentive for American international policy. As colonialism played a significant role in shaping the world, the 'war on terror' is produced and orchestrated carefully to serve the same colonial domination under the pretext of peace, progress and civilization (Khamas, 2013). The colonial desire to master and control is now re-articulated in the context of imperialism's 'war on terror.' Muslims upbraid America for producing and reproducing the images of suppressed Muslim women and argue that these images have been strategically used to advance US imperialism; and they contend that the ulterior motive behind portrayals of Muslim communities as backward and retarded societies is the desire of imperialism to dominate the world with no persuasive ideology of hegemony. On the other hand, America strives to convince that attacking these Muslim countries is a human project called 'liberation'. National-security interests, human rights and women's rights are now repeatedly cited as the fundamental objectives of the imperial interventions. Whatever the argument, the 'war on terror' images have naturalized abhorrence and violence in these countries and relegates all the problems in those societies to their culture.

\section{Conclusion}

Throughout history, governments have been aware of the power in bombarding the public with images. Thus, it is no wonder that both sides are conscious of the fact that images play a significant role in political battles and they have the potency to act as agents in political conflicts. Having understood the importance of images, the Ping-Pong match of indictment and rebuttal between the West and the Muslim countries emerged. Each side has been producing images to hurt each other and to reinforce their ideologies. Images of 9/11 attacks gave birth to the re-currency of anti-Islamic images which spread violence and hatred towards Muslims. When the 'war on terror' began, the circulation of Abu-Gharib images brought about anti-American sentiments. These images have been at war in inciting hatred and gaining support. Exposure to these images in the global media has a significant impact on one's culture; it destructs individual's cultures and diversity. These images are potent enough to lure people into holding beliefs that compromise the West/Muslim ideologies. They possess the power to persuade others to share certain views and hold certain values parallel with the intended ideologies. The clandestine war of images is, in fact, a propaganda war which affects a collective consciousness. It is a war fought with images schemed to disturb the enemy and designed to shock and demoralize. Images, which are the ends and means, artillery and object, and cause and effects in modern warfare, clone themselves ceaselessly to taint the collective psyche of global populations. The clash of images is indicative of current image culture where images are powerful tools of persuasion when they array against and engage with one another.

\section{References}

Alsultany, E. (2013). Arabs and Muslims in the media after 9/11: Representational strategies for a "postrace" era. American Quarterly, 65(1), 161-169. http://dx.doi.org/10.1353/aq.2013.0008

Anden-Papadopoulos, K. (2007). The Abu Gharib torture photographs: News frames, visual culture, and the power of images. Journalism, 9(1), 5-30. http://dx.doi.org/10.1177/1464884907084337

Apel, D. (2005). Torture culture: Lynching photographs and the images of Abu Gharib. Artform (Summer).

Crime and Punishment/Saudi Arabian Rape Case/Ali Interview. Anderson Cooper 360, CNN, November 29, 2007.

Dabashi, H. (2011). Brown Skin, White Mask. New York: Pluto Press. History review, 95, 21-44.

Eman, K. A. (2013). Appropriating a Feminist Discourse in the War on Terror. Universitat Autonoma de Barcelona. Dissertation.

Hankiss, E. (2001). Symbols of Destruction. Paper for Social Science Research Council New York. 
Hatfield, K. L. (2006). A culture of terror rises out of the dust: A rhetorical analysis of iconic imagery on the aftermath of 9/11. Ohio University. Dissertation.

Jabbra, N. W. (2006). Women, words and war: Explaining 9/11 and justifying U.S. military action in Afghanistan and Iraq. Journal of international women's studies, 8(1), 236-255.

Kellner, D. (2007). The Media in and after 9/11. International journal of Communication, 1, 123-142.

Kennedy, L. (2003). Remembering September 11: Photography as cultural diplomacy. International Affair, 79(2), 315-326. http://dx.doi.org/10.1111/1468-2346.00310

Lakoff, G. (2004). Don't think of an elephant! Know your values and frame the debate. White River, VT: Chelsea Green Publishing.

Lucaites, J. L., \& Hariman, R. (2001). Visual rhetoric, photojournalism, and democratic public culture. Rhetoric Review, 20, 37-42.

Lutz, C. A., \& Collins, J. L. (1993). Reading National Geographic. Chicago: The University of Chicago Press.

Matthews, M. (2004). Abuse tailored to Arabs, experts say. Baltimore Sun, 5 A.

Mirzoeff, N. (1998). What is visual culture? In N. Mirzoeff (Ed.), The visual culture reader (pp. 3-13). London: Routledge.

Mirzoeff, N. (2006). Invisible Empire: Visual Culture, Embodied Spectacle, and Abu Gharib. Political history review, (95). http://dx.doi.org/10.1215/01636545-2006-95-21

Mitchell, W. J. T. (1994). Picture theory: Essays on verbal and visual representation. Chicago, IL: University of Chicago Press.

Rachel, B. J. (2007). (Re)Envisioning Self and Other: Subverting Visual Orientalism throughout the Creation of Postcolonial Pedagogy. The University of North Carolina at Greensboro. Dissertation.

Remarks by Secretary of State Colin L. Powell at the launch of the Educational and Cultural Affairs Exhibit. "After September 11th: Images from Ground Zero", US Department of State: Office of the Spokesman press release, 27 Feb. 2002.

Sturken, M., \& Cartwright, L. (2001). Practices of looking: An introduction to visual culture. Oxford University Press.

Whitlock, G. (2007). Soft Weapons: Autobiography in Transit. Chicago, University of Chicago press. http://dx. doi.org/10.7208/chicago/9780226895277.001.0001

Zeiny, J. E., Hashim, S. R., Noraini, Y. M., Hamdan, M. M. R., Ismail, S., \& Peivand, Z. (2014). Educating prisoners of tradition: Visual narratives of Afghan women on social media. International Education Studies, $7(3)$.

\section{Copyrights}

Copyright for this article is retained by the author(s), with first publication rights granted to the journal.

This is an open-access article distributed under the terms and conditions of the Creative Commons Attribution license (http://creativecommons.org/licenses/by/3.0/). 